\title{
Early Auditory Rehabilitation of an Infant with Unilateral Profound Hearing Loss: A Case Study
}

\author{
Jieun Yoon', Jinsook Kim², Hyejin Park ${ }^{1}$ \\ 'Department of Speech Pathology and Audiology, Graduate School, Hallym University, Chuncheon, Korea \\ ${ }^{2}$ Division of Speech Pathology and Audiology, Research Institute of Audiology and Speech Pathology, College of Natural Sciences, Hallym University, \\ Chuncheon, Korea
}

\author{
일측성 고심도 난청 영아의 조기청능재활 사례 보고 \\ 윤지은 ${ }^{1}$ 김진숙 ${ }^{2} \cdot$ 박혜진 $^{1}$
}

한림대학교 일반대학원 언어병리청각학과 ${ }^{1}$, 한림대학교 자연과학대학 언어청각학부, 청각언어연구소 ${ }^{2}$

\begin{abstract}
Purpose: The purpose of this paper was to report a result of early intervention for an infant with a congenital profound unilateral hearing loss in the right ear. Methods: The infant was identified as his hearing problem through newborn hearing screening test and diagnosed with unilateral hearing loss at 5 months of age. The early intervention program was applied from 9 months to 12 months of age to prompt listening and spoken language acquisition. Korean aural rehabilitation for infants and toddlers, the program was applied to the infant, focused on parent education as a mean of facilitating the child's language acquisition. The mother and grandmother participated in the intervention. The program was carried out once per two weeks for 3 months, and each session lasted 90 minutes. The listening, speech, and language evaluations were conducted before and after applying early intervention for 3 months to check the progress on each area. Results: The infant scored within normal range across evaluations applied on both, but largely improved especially on the vocabulary and general language development screening test at the second evaluation, taken at the 12 months of age. Conclusion: The review for what should be considered for children with the unilateral hearing loss was discussed.
\end{abstract}

Key Words: Unilateral hearing loss, Newborn hearing screening, Early intervention, Korean aural rehabilitation for infants.

Received: February 25, 2016 / Revised: March 20, 2016 / Accepted: March 25, 2016

Correspondence: Hyejin Park, Department of Speech Pathology and Audiology, Graduate School, Hallym University, 1 Hallimdaehak-gil, Chuncheon 24252, Korea

Tel: +82-33-248-3310 / Fax: +82-33-256-3420 / E-mail: hpark@hallym.ac.kr

\section{INTRODUCTION}

난청은 선천성 질환 중 흔한 질환 가운데 하나로, 신생아의 선 천성 난청 유병률은 1,000명당 0.9 5.9명에 이른다(Korean Otology Society \& The Korean Audiology Society, 2011). 청 력손실은 언어발달뿐 아니라 다방면에 걸쳐 아동 발달에 영향 을 미치기 때문에, 그 영향을 최소화하고자 세계적으로 난청의 조기 발견과 조기 재활의 중요성이 대두되고 있다(American Academy of Pediatrics, Joint Committee on Infant Hearing, 2007). 우리나라에서도 2007년 16개 지역에서 신생아를 대상 으로 신생아 청각선별검사 시범 사업을 실시하기 시작한 이래,
2008년에는 해당 지역을 32개 지역으로 확대 시행하였다. 2015 년 현재 전국의 기초 생활 수급자와 차상위계층에 국한하여 사 업을 진행하였고, 2018년부터는 전국의 모든 신생아를 대상으 로 청각선별검사를 실시할 예정이다. 신생아 청각선별검사의 실 시로 양이의 고심도 난청뿐 아니라, 조기 발견이 쉽지 않았던 경도 난청 및 일측성 난청까지, 대부분의 선천성 난청 영아를 조기에 발견할 수 있게 되었으며, 더 나아가 조기 재활을 통해 각 아동의 청력손실 특성에 적합한 재활 서비스 제공이 가능하 게 되었다.

일측성 난청이란 한쪽 귀에만 난청이 발생하는 것을 가리키 며, 청력손실 정도는 경도에서 심도에 이르기까지 매우 다양하 
다. 우리나라에서 12 세 이상 청소년의 일측성 난청 발병률은 $5.1 \%$ 에 달해 많은 학생들이 일측성 난청을 경험하는 것으로 보고되고 있으나(Ministry of Health and Welfare \& Centers for Disease Control and Prevention, 2012), 12세 이전, 특히 신생아의 일측성 난청 발병률은 따로 보고된 바가 없다. 미국의 경우를 참고하면, 신생아 청각선별검사가 시행되기 이전에 일측 성 난청의 평균 진단 연령은 8세였으나(Brookhouser et al., 1991), 신생아 청각선별검사 이후 평균 9개월에 일측성 난청을 진 단할 수 있게 되었고(Fitzpatrick et al., 2015), 신생아에서 일측 성 난청 발병률은 1,000명당 약 1명이지만(Prieve et al., 2000), 청소년기에서는 약 3 5\%의 아동이 경도 이상 $(>25 \mathrm{~dB})$ 의 일측 성 난청이 있으며(Niskar et al., 1998), 미도 이상 $(>15 \mathrm{~dB})$ 의 청 력손실을 포함할 경우 그 수는 약 $19.5 \%$ 에 이르는 것으로 알려 져 있다(Shargorodsky et al., 2010).

이렇게 많은 아동 및 청소년들이 일측성 난청을 경험하고 있 으나, 일측성 난청은 고심도 난청에 비해 상대적으로 연구나 임 상에서 거의 관심을 받지 못하였다. 따라서 일측성 난청이 아 동의 발달에 어떤 영향을 미치는지, 어떤 재활이 효과적인지에 등에 대한 연구는 많지 않다. 일측성 난청으로 야기되는 청각 학적인 문제는 1) 소리의 방향성 변별, 2) 일측성 난청이 있는 쪽 귀의 말지각, 3) 특히 건청인 귀 쪽에 배경 소음이 있을 때의 말지각, 그리고 4) 양이 합산의 손실 등이다(Bess et al., 1986; Bovo et al., 1988). Bovo et al.(1988)은 115명의 일측성 난청 아동을 대상으로 한 연구에서 $83 \%$ 의 아동들이 소리의 방향성 변별에 어려움이 있고 $63 \%$ 는 소음 속 말소리의 지각 및 변별에 어려움을 느끼며, 더 나아가 $32 \%$ 는 선생님의 말소리를 이해하 기 어렵다고 보고하였다. 이는 모두 일측성 난청으로 인해 양이 효과를 누리지 못하는 데서 발생하는 문제들이다. 우리는 두 귀를 이용하여 들음으로서 양이 합산, 소리의 방향성 확인, 두 영 효과, 차폐를 통한 양이 방출의 이점을 갖게 된다. 양이로 소 리를 들었을 때 한쪽으로 들었을 때보다 $3 \mathrm{~dB}$ 의 이득이 있는 데, 이는 단음절어인지에서 $18 \%$, 문장인지에서 $30 \%$ 정도 수행 력을 향상시키는 데 도움이 된다(Konkle \& Schwartz, 1981). 일측성 난청의 경우 이러한 양이 효과를 누리지 못하기 때문에 말소리 인지 능력이 저하될 뿐 아니라, 난청이 있는 귀의 방향 에서 들려오는 소리를 듣는 데 어려움을 겪고, 소리의 방향성을 구분하는 능력이 저하되며, 특히 소음상황에서 더 어려움을 겪 게 된다.

일측성 난청은 듣기뿐 아니라 언어발달에도 영향을 미친다. 일측성 난청 영아를 대상으로 한 연구결과에 의하면, 일측성 난 청 아동들은 생후 1 년 동안 옹알이의 양이 줄어들고(Ruscetta et al., 2005), 약 12 개월에 첫 낱말을 발화하여 첫 낱말을 발화 하는 시기는 건청 아동과 큰 차이가 없지만, 두 개의 단어 조합
이 나타나는 시기는 약 23 개월로 건청 아동보다 약 5 개월 정도 지체된다(Kiese-Himmel, 2002). 또 15명의 일측성 난청 유아 의 언어발달을 추적한 또 다른 연구에서는 12 개월에 $34 \%(5$ 명) 의 아동들이 언어발달 지체를 보였다고 보고하였다(Sedey et al., 2002). 이 연구들은 비록 다른 한쪽 귀의 청력이 정상이라 해도 일측성 난청이 언어발달 초기부터 영향을 끼칠 수 있음을 보여준다. 그러나 조기에 난청을 발견하고 조기 재활을 받은 31 명의 일측성 고도난청 영아를 대상으로 한 최근 연구는 이 아 동들이 $12,24,36,48$ 개월에 듣기 및 언어발달에서 건청 아동 들과 차이가 없었음을 보고하여, 일측성 난청 아동의 듣기 및 언 어 발달에 조기 재활이 필요함을 증명하기도 하였다(Fitzpatrick et al., 2015). 학령전기나 학령기 일측성 난청 아동의 언어발 달에 대한 연구들은 서로 상이한 결과를 보고하고 있다. Klee \& Davis-Dansky(1986)는 6 13세 사이인 25명의 일측성 난청 아동의 언어능력이 6개의 표준화된 검사에서 또래 건청 아동 들과 차이가 없었다고 하였다. 그러나 Borg et al.(2002)은 4 5 세인 일측성 난청 아동의 언어발달이 또래 건청 아동들보다 지 체되었다고 보고하였고, 다른 연구에서도 일측성 난청 아동들 이 그 형제들보다 언어발달이 뒤떨어져 있으며, 언어발달지체 가 청소년기까지 지속되는 것으로 확인하였다(Fischer \& Lieu, 2014).

일측성 난청 아동의 언어발달에 대한 연구 중 일부는 난청 발생 방향이 언어 및 인지 발달에 영향을 미칠 수 있음을 보고 하고 있다. 연구 중 일부는 오른쪽에 난청이 발생한 경우 왼쪽 에서 발생했을 때보다 언어 검사에서 수행력이 낮고(Bess et al., 1986; Niedzielski et al., 2006), 왼쪽에 난청이 발생한 경우 비언어 과제의 수행이 더 낮다고 하였다(Niedzielski et al., 2006). 그러나 다른 연구에서는 난청의 방향에 따라 언어과제 나 비언어과제의 수행능력에 차이가 없음을 보고하기도 하였 다(Bovo et al., 1988; Dancer et al., 1995).

언어발달 외에 일측성 난청은 아동의 학업 수행 및 학교생활 에도 영향을 미칠 수 있다. 일부 연구는 일측성 난청 아동과 건 청 아동이 학업 성취도에서 유의미한 차이가 없다고 보고하였 으나(Keller \& Bundy, 1980), 이후의 여러 연구에서 일측성 난 청 아동들의 학업 수행 지체가 확인되었다(Bess \& Tharpe, 1986; Bovo et al., 1988; Dancer et al., 1995). Bess와 Tharpe (1986)는 60명의 일측성 난청 아동의 학업 수행을 연구한 결과 $35 \%$ 의 아동이 최소한 한 학년을 유급한 것을 확인하였는데, 이는 건청 아동의 평균 유급 비율 $3.5 \%$ 에 비해 10 배 높은 것이 다. 또한 일측성 난청 아동들 중 $54 \%$ 는 특수교육의 도움이 필 요한 것으로 나타났다(English \& Church, 1999). 이러한 결과 는 최근 6 12세 일측성 난청 아동 49명을 3년 동안 추적한 종 단연구에서도 확인되었는데, 연구에 참여한 49 명의 아동 중 약 
$25 \%$ 의 아동이 학업에 어려움을 보였다(Lieu et al., 2010). 학업 수행의 어려움 외에 일측성 난청 아동들은 심리 및 행동문제 를 보일 위험도 큰 것으로 보고되고 있다. 일측성 난청 아동들 은 건청인 또래 아동이나 형제보다 주의가 산만하거나, 자신감 이 떨어지고, 학급활동에의 참여도가 낮으며 약 $20 \%$ 정도가 행동문제를 가지고 있는 것으로 나타났다(Bess \& Tharpe, 1986; Dancer et al., 1995; Lieu, 2013). 또한 일측성 난청은 또 래와의 관계 및 사회적인 자신감(social confidence)에도 영향 을 미친다. 일측성 난청 25 명을 건청 또래 25 명과 비교한 한 연 구에 의하면 난청 그룹은 또래에게 공격적인 성향을 보이는 비 율이 높았고, 또래와의 상호작용을 시작하지 않는다고 하였다 (Culbertson \& Gilbert, 1986).

과거 일측성 난청은 건강한 다른 쪽 귀의 정상적인 청력으 로 인해 '언어발달 및 학습에 아무 문제가 없는 것'으로 인식되 어 왔다(Hallmo et al., 1986). 그러나 최근 30년간의 연구 결과 에서 일측성 난청과 언어발달, 학업 수행, 행동 문제와의 연관성 이 확인되면서(Bess \& Tharpe, 1986; Culbertson \& Gilbert, 1986) 일측성 난청에 대한 인식과 관심, 재활 방침이 변화하고 있다(Brookhouser et al., 1991). 또한 일측성 난청의 경우에도 양측성 난청 아동과 마찬가지로 청각자극의 부족으로 인해 대 뇌 피질의 청각 영역이 재조직되므로(Rouger et al., 2012), 이를 방지하기 위한 조기 재활이 필요하다. 그러나 양측성 난청 영아 가 생후 1 년 이내에 재활을 시작하였을 때 언어능력이 향상됨은 많은 연구를 통해 증명된 반면(Yoshinaga-Itano et al., 1998), 일측성 난청 영유아의 조기 재활에 대한 연구는 매우 부족하 다. 이에 본고에서는 일측성 난청으로 진단받은 영아의 조기 재 활 사례를 보고하고, 이를 통해 일측성 난청 영아의 조기 발견 의 필요성 및 재활 방법과 방향 등에 대해 논의해 보고자 한다. 본고에서 보고할 영아는 서울특별시 강동구에 소재한 강동보 건소와 한림대학교 대학원 언어청각학과 BK21+ PLUS 영유아 팀이 공동으로 추진하고 있는 신생아 청각선별검사 후 조기재 활의 활성화를 위한 프로그램'에 참여하여, 강동보건소에서 난 청 확인 후 한림대학교로 재활을 의뢰하였다. 아동의 재활을 위해 현재 한림대학교 언어청각학과 BK21 PLUS의 '청각언어 재활 프로그램 개발연구 사업팀 중 영유아팀에서 개발 중인 영 아의 청능재활(Korean aural rehabilitation for infants, KARI) 프로그램을 실시하였다.

\section{MATERIALS AND METHODS}

\section{배경정보}

사례보고 대상 영아는 2014년 10월 27일생 남자 영아이다. 영 아의 어머니의 보고에 의하면 영아는 신생아 선별검사에서 재
검판정을 받아 생후 5 개월에 청성뇌간유발반응검사를 실시하 였으며, 검사 결과 좌측 귀는 정상이나 우측 귀에 $90 \mathrm{~dB} \mathrm{HL}$ 이 상의 심도 감각신경성 난청이 있는 것으로 진단받았다. 영아의 어머니는 일측성 난청 확진 후 보장구 또는 조기 재활의 필요성 에 대한 안내는 받지 못하였다고 보고하였으며, 따라서 현재 보 장구를 사용하지 않고 있다. 강동보건소를 통하여 본 연구팀에 의뢰된 후, 2015년 7월 30일 첫 상담 및 평가를 실시하였고, 2015년 8월 12일부터 2015년 10월 29일까지 약 3개월에 걸쳐 총 9회의 재활을 실시하였다.

\section{조기 재활}

2015년 8월부터 10월까지 한림대학교 언어청각학과 BK21 PLUS의 '청각언어재활 프로그램 개발연구' 사업팀 중 영유아 팀 연구원이 2주마다 가정을 방문하여 부모 교육 및 재활을 실 시하였다. 재활에는 본연구팀에서 제작한 KARI의 재활 자료 중 “우리아이와 매일매일 어떻게 말할까요?”를 이용하였다. “우 리아이와 매일매일 어떻게 말할까요?"는 일상생활에서 영유아 에게 청각 및 언어 자극을 제시하는 방법을 상황별로 엮은 부 모교육용 자료로 각 상황별로 부모가 제시할 수 있는 언어자 극 방법의 설명과 그 예를 담고 있다. "우리아이와 매일매일 어 떻게 말할까요?"의 16 개 목록은 다음과 같다; '아침에 일어날 때, '기저귀 갈 때', '목욕 전후, '마사지 할 때', '젖 먹일 때', '옷을 입고 벗을 때', '아이에게 밥 먹일 때', '책 읽기', '공 가지고 놀기', '아이 인형이나 곰 인형 가지고 놀기', '퍼즐 가지고 놀기', '소꿉 놀이 하기', '놀이터에서 놀기', '색깔찰훍 놀이', '빨래하기', '산책 하기'. 이 중 일부를 아동의 생활과 발달에 맞게 적절히 선택하 여 3개월 동안 영아의 재활에 사용하였다. 그 외 부모 상담에 는 일측성 난청이 듣기, 말하기, 의사소통, 학습 등에 미치는 영 향에 대한 설명을 포함하였고, 질문지를 활용한 질의응답 시간 을 가졌다. 부모의 질문은 보장구의 필요성, 훈육이 가능한 시 기, 성별에 따른 발성발달 차이, 일측성 난청이 언어발달 및 학 습에 미치는 영향 등이었다.

재활에는 영아의 어머니와 할머니가 주 양육자로 함께 참여 하였다. 연구원이 먼저 시범을 보이고, 부모와 할머니가 활동에 참여하여 재활을 실시하는 연구원을 모방하거나 평소 영아에게 하듯이 말을 하도록 하였다. 이후 양육자와 함께 "우리아이와 매 일매일 어떻게 말할까요?"의 교육자료를 보며 각 상황을 어떻게 응용할 수 있는지 이야기하였다. 재활 활동 및 상담을 포함하여 재활 시간은 평균 약 90 분이었다. 부모교육을 효율적으로 실시 할 수 있도록 연구자들이 방문하지 않는 때에는 '일일점검표를 활용하여, 매일 영아에게 집중적인 언어자극을 준 상황과 내용, 자발적인 발성 및 모델링 시 발성 등을 기록하도록 하였다. 일 일점검표의 내용은 연구원이 방문하였을 때 확인하고, 부모가 
가정에서 실시하는 재활 방법의 방향을 이끌어주는 지침표로 사용하였다. 또한, 좀 더 밀도 있는 부모교육자료로 구조화된 '질문지'를 이용하여 난청 및 재활 전반에 대한 부모의 질문을 실시간으로 매일 메모하게 하여 연구원이 방문했을 때 직접 대 답해주는 형식으로 부모교육을 실시하였다.

\section{초기 및 진전 평가}

조기 재활의 기초선을 확인하고, 3 개월간의 재활 후 영아의 진전도를 확인하기 위해 발성 및 말소리, 듣기, 언어 및 사회적 의사소통, 전반적 발달의 4 개 영역에서 총 7 개 검사를 실시하였 다. 기초선을 확인하기 위한 검사는 2015년 7월 30일(생활연령: 9개월)에, 진전도를 확인하기 위한 검사는 3개월 후인 2015년 10 월 29일(생활연령: 12 개월)에 시행하였으며, 검사 및 재활은 모두 영아의 집에서 이루어졌다. 본고에 보고한 평가 영역 및 검사 도구는 Table 1에 제시하였다.

\section{발성 및 말소리}

발성 및 말소리 평가도구로는 The Stark Assessment of Early Vocal Development-Revised (SAEVD-R)(Nathani et al., 2006) 을 사용하였다. SAEVD-R은 영아의 초기 발성발달 단계를 평 가할 수 있으며, 발달에 따라 총 5단계 23개의 발성유형으로 나 누어져 있다. 1 단계는 반사적 발성단계, 2 단계는 발성조절단계, 3 단계는 확장단계, 4 단계는 기본음절단계, 5 단계는 상위음절 단계로 구성되어 있다. 9 개월과 12 개월의 발성발달 변화를 분 석하기 위해 자유놀이 및 Communication and Symbolic Behavior Scales Developmental profile (CSBS DP) 검사 상황에 서 약 40분 동안 영아가 자발적으로 산출한 발성을 수집하였다. 발성 자료 수집은 디지털 비디오 카메라(SOC-HDR-XR150; Sony, Tokyo, Japan)를 이용하였고, 수집 후 제1저자가 전사 및
SAEVD-R을 이용한 발달 단계 분석을 실시하였다. 또한 발성 시 산출한 자음의 종류와 위치를 분석하여 조음 발달의 변화 를 살펴보았다.

듣 기

듣기 발달 도구로는 The Korean version of LittlEARS ${ }^{\circledR} \mathrm{Au}-$ ditory Questionnaire (LEAQ-K)(Son et al., 2015), Categories of Auditory Performance (CAP)(Archbold et al., 1995)를 사용 하였다. LEAK-Q는 생활연령 또는 듣기연령 0 24개월 사이의 건청 영유아와 인공와우·보청기를 착용하는 청각장애 아동의 듣기 발달을 평가는 검사도구이다. 총 35문항으로 구성되어 있 으며 '예' 혹은 '아니오'에 체크하여 '예'라고 대답한 문항의 수가 총점이 된다. 본고에서는 원점수를 그대로 사용하였으며, 아동 의 점수를 Sohn et al.(2015)의 논문에서 보고한 건청 아동 예 측점수와 비교하여 발달 정도를 확인하였다.

$\mathrm{CAP}$ 는 일상생활에서의 관찰을 통하여 총 8 개로 나누어진 범주로 듣기 기술 발달을 평가한다. 8개 범주는, 환경음의 유무 를 알지 못함 0 , 환경음의 유무를 앎 1 , 말소리에 반응함 2 , 환 경음을 확인함 3 , 독화 없이 약간의 말소리를 변별함 4 , 독화 없 이 일상적인 구문을 이해함 5 , 독화 없이 대화를 이해함 6 , 잘 모르는 사람과 전화가 가능함 7이다.

\section{언어 및 사회적 의사소통}

언어 및 사회적 의사소통을 평가하기 위한 도구로는 $\mathrm{Se}-$ quenced Language Scale for Infant (SELSI)(Kim et al., 2003), Korean MacArthur-Bates Communicative Development Inventories (K MBCDI)(Bae \& Kowk, 2011), CSBS DP (Wetherby \& Prizant, 2002)를 사용하였다.

SELSI는 표준화된 검사도구로, 전반적 언어 발달정도를 체

Table 1. Evaluation areas and the assessment tools for each area

\begin{tabular}{|c|c|c|c|c|c|}
\hline \multirow{2}{*}{ Evaluation areas } & \multirow{2}{*}{ Assessment tools } & \multirow{2}{*}{ Authors } & \multirow{2}{*}{ Scales/scores } & \multicolumn{2}{|c|}{ Age at evaluation } \\
\hline & & & & 9 month & 12 months \\
\hline Speech development & SAEVD-R & Nathani et al. (2006) & Developmental level & $\bigcirc$ & 0 \\
\hline \multirow[t]{2}{*}{ Auditory development } & LEAQ-K & Sohn et al. (2015) & Raw score & $\bigcirc$ & $\bigcirc$ \\
\hline & CAP & Archbold et al. (1995) & Category & $\bigcirc$ & $\bigcirc$ \\
\hline \multirow[t]{4}{*}{$\begin{array}{l}\text { Language and } \\
\text { communication development }\end{array}$} & SELSI & Kim et al. (2003) & $\begin{array}{l}\text { Raw score, percentile } \\
\text { Equivalent age }\end{array}$ & $\bigcirc$ & $\bigcirc$ \\
\hline & K MBCDI & Bae \& Kowk (2011) & Raw score, percentile & O & 0 \\
\hline & CSBS DP & Wetherby \& Prizant (2001) & Raw score, Percentile & $x$ & O \\
\hline & CSBS checklist & Lee \& Jang (2004) & & & \\
\hline Developmental screening & DEP & Jang et al. (2008) & Raw score, percentile & $\bigcirc$ & $x$ \\
\hline
\end{tabular}

SAEVD-R: The Stark Assessment of Early Vocal Development-Revised, LEAQ-K: LittlEARS ${ }^{\circledR}$ Auditory Questionnaire-Korean, CAP: Categories of Auditory Performance, SELSI: Sequenced Language Scale for Infant, K MBCDI: Korean MacArthur-Bates Communicative Development Inventories, CSBS DP: Communication and Symbolic Behavior Scales Developmental Profile, DEP: Developmental assessment for the Early intervention Program planning 
크할 수 있다. SELSI는 수용언어와 표현언어로 구분되어 있으 며, 4 35개월을 16 개 월령구간으로 나누어 각 월령구간당 4 개 의 문항을 제시하고 있다. $\mathrm{K} \mathrm{MBCDI}$ 는 표준화된 검사도구로, 아동의 어휘 및 제스처 발달을 체크할 수 있다. 아동의 어휘 및 제스처 발달을 평가하기 위해 영아용(8 17개월) 검사지를 사 용하였다. 영아용 검사지는 총 284 개의 낱말의 표현 및 이해, 60 개의 제스처와 놀이관련 문항을 포함하고 있다. CSBS DP는 영유아의 의사소통 기능 발달 평가에 널리 쓰이는 평가도구이 다. 아동의 행동은 사회적 행동(감정표현 및 눈맞춤, 의사소통, 제스처), 언어 표현(소리, 단어), 상징행동(이해, 물건 사용)의 7 가지 항목으로 나누어 평가한다. 본 사례에서는 태엽장난감, 주 머니, 풍선, 비누방울, 병 속에 든 과자, 책, 인형, 소꿉놀이, 블 록을 이용하여 의사소통 행동을 유도하였으며, 7 가지 평가항 목을 모두 측정하였다. 본격적인 검사를 시작하기 전 아동과의 라포 형성을 위해 장난감 버스를 이용하여 약 10 15분 정도 아동과 놀이를 한 후 검사를 진행하였다. 또 아동의 어머니에 게 CSBS DP checklist를 작성하도록 하였다.

\section{전반적 발달}

전반적 발달 평가 도구로는 Developmental assessment for the Early intervention Program planning (DEP)(Jang et al., 2008)을 사용하였다.

$\mathrm{DEP}$ 는 표준화된 검사도구로, 0 36개월 영유아의 전반적 발 달을 평가할 수 있다. 평가 영역은 대근육 운동기술, 소근육 운 동기술, 의사소통, 사회정서, 인지, 기본생활의 6 개 영역이며, 모 두 344문항으로 이루어져 있고 각 문항에 '예', '가끔', '아니오'로 대답하도록 구성되어 있다. 대상 아동의 전반적 발달정도를 선 별 진단하기 위해 본 검사를 사용하였다.

\section{평가절차 및 신뢰도 분석}

$\mathrm{SAEVD}-\mathrm{R}$ 을 위한 자료수집과 CSBS DP 검사는 제 1 저자가 영아를 대상으로 직접 실시하였으며, LEAQ-K, CAP, SELSI, $\mathrm{K} \mathrm{MBCDI}, \mathrm{DEP}$ 는 아동의 어머니가 직접 검사지에 기록하였 다. 전반적 발달 평가인 $\mathrm{DEP}$ 은 초기 평가에서 정상 발달임을 확인하였고, 3 개월 동안의 관찰에서 특이점이 발견되지 않았으 며, 발달상 문제가 없다는 부모의 보고에 따라 3 개월 진전평가 에서 제외하였다.

아동 발성 전사 및 분석의 신뢰도를 확인하기 위해 영유아 아동의 발성과 SAEVD-R에 익숙한 다른 대학원생이 분석에 참여하였고, 2 명의 분석자가 모두 동의한 경우 해당 발성으로 인정하였다. 의견이 불일치할 경우에는 제 3 전문가 의견을 확인 하여 재분석하였다.
Table 2. Speech development assessment outcomes

\begin{tabular}{|c|c|c|}
\hline Age at evaluation & $\begin{array}{c}\text { First evaluation } \\
(9 \text { months })\end{array}$ & $\begin{array}{c}\text { Second evaluation } \\
\text { (12 months) }\end{array}$ \\
\hline \multicolumn{3}{|l|}{ SAEVD-R } \\
\hline 1 level & $12 \%$ & $2 \%$ \\
\hline 2 level & $6 \%$ & $29 \%$ \\
\hline 3 level & $34 \%$ & $31 \%$ \\
\hline 4 level & $21 \%$ & $14 \%$ \\
\hline 5 level & $27 \%$ & $25 \%$ \\
\hline \multicolumn{3}{|c|}{ Consonant production } \\
\hline $\begin{array}{l}\text { Initial position } \\
\text { of syllables }\end{array}$ & 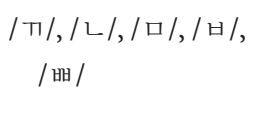 & 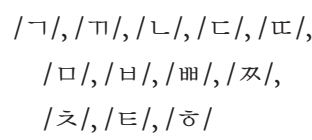 \\
\hline $\begin{array}{l}\text { Final position } \\
\text { of syllables }\end{array}$ & //, /ㅁ/ & $\begin{array}{l}\text { /ᄀ/,/ / /, /ᄃ/,/ㅁ/,//, } \\
\text { /০/ }\end{array}$ \\
\hline
\end{tabular}

SAEVD-R: The Stark Assessment of Early Vocal Development-Revised

\section{RESULTS}

\section{발성 및 말소리}

SAEVD-R을 이용하여 9개월과 12 개월의 발성 및 산출 자 음 목록을 분석한 결과는 Table 2에 제시하였다. 발성 분석 결 과 초기평가에서 전체 발화 중 1 단계 5 단계까지의 발성이 차지 하는 비율은 각각 차례대로 $12 \%, 6 \%, 34 \%, 21 \%, 27 \%$ 였다. 3 개 월 후, 진전평가에서 1 5 단계의 발성이 차지하는 비율은 각각 $2 \%, 29 \%, 31 \%, 14 \%, 25 \%$ 였다.

발성 분석과 더불어 영아가 산출한 자음 목록을 분석한 결 과, 초기 평가 시 초성에서 5 개의 자음, $/ \pi /, /$ ㄴ/, /ㅁ/, /ㅂ/, /ㅃ/, 종성에서 2 개의 자음, /ㄴ/, /ㅁ을 산출하였다. 3 개월 진전 평가 시, 초성에서 12 개의 자음, /ᄀᄀ/, / T//, /ㄴ/, /ㄷ/, /匹/, /ㅁ/, /ㅂ/, / 빠/, /ㅉ/, /ㅊ/, /E/, /ㅎ/, 종성에서 7종성 중 /ㄹ/을 제외한 모든 종성을 산출하는 것으로 나타났다.

\section{듣 기}

$\mathrm{LEAQ}-\mathrm{K}$ 를 이용하여 듣기 발달을 평가한 결과, 초기 평가 에서 19점을, 3 개월 후 진전 평가에서 29점을 기록하였다. 아동 의 점수를 Figure 1A에 Son et al.(2015)에서 보고한 건청 또래 아동의 듣기 발달 평균 예측 점수와 함께 제시하였다. 9 10개월 과 12 13개월의 건청 아동 예측점수(범위)는 각각 19(11 27), 23(15 31)점으로 대상 아동의 점수는 모두 예측점수 범위 안 에 포함되었다.

$\mathrm{CAP}$ 를 이용하여 듣기 기술 발달을 평가한 결과, 초기평가에 서는 독화 없이 약간의 말소리를 변별하는 범주인 4 를 나타내 었고, 진전 평가에서는 독화 없이 일상적인 구문을 이해함 범 주 5 를 나타내었다(Figure 1B). 


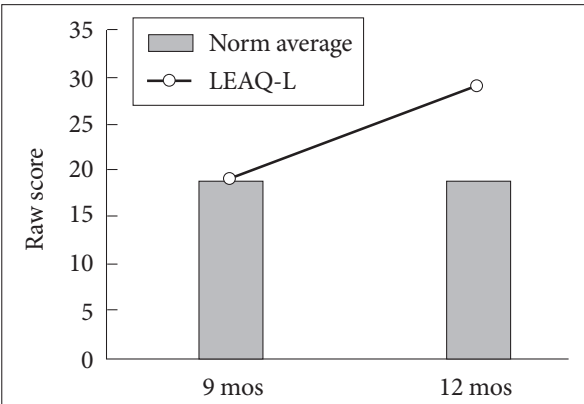

A

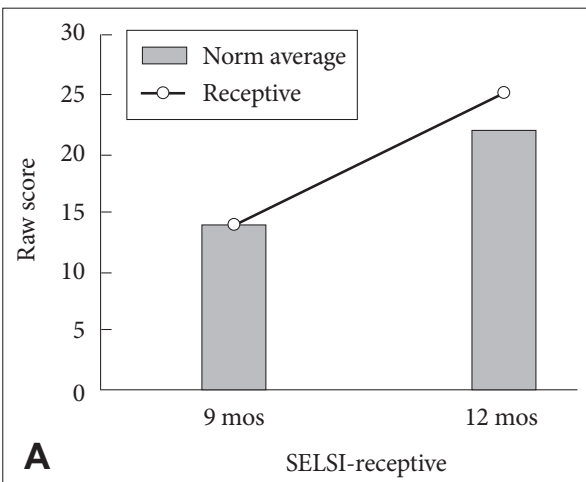

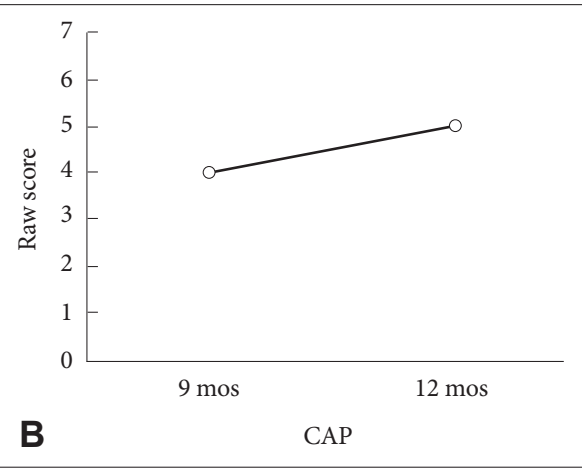

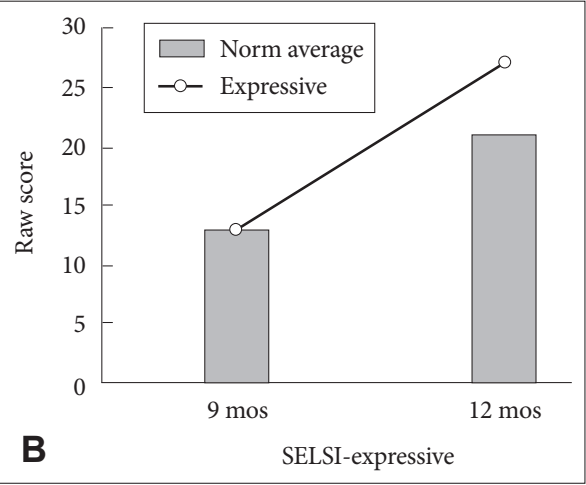

Figure 1. Auditory development assessment outcomes at the first and second evaluation. A: LEAQ-K (The Korean version of LittIEARS auditory Questionnaire). B: Categories of Auditory Performance. The bar graphs show the normal means provided by Sohn et al. (2015), and the line above the bars shows the child's performance.

Figure 2. Language assessment outcomes using SELSI at the first and second evaluation. A: SELSI receptive language. B: SELSI expressive language. The bar graphs show the normal means provided by the test manual, and the line above the bars shows the child's performance. SELSI: Sequenced Language Scale for Infant.

\section{언어 및 사회적 의사소통}

SELSI를 이용하여 전반적 언어발달을 평가한 결과, 수용언 어는 초기평가 시 14점(50\%ile)으로 등가월령 8개월에 해당하 였고. 3개월 진전평가에서는 25점(65\%ile)으로 등가월령 14개월 에 해당하였다(Figure 2A). 표현언어는 초기평가 시 13점(50\% ile)으로 등가월령 8개월에 해당하였고, 진전평가에서는 27점 (90\%ile)으로 등가월령 16 개월에 해당하는 것으로 나타났다 (Figure 2B). Figure 2에 아동의 각 점수를 검사 안내서에서 제 공하는 평균점수와 함께 제시하였다.

$\mathrm{K} \mathrm{MBCDI}$ 를 이용하여 어휘발달을 평가한 결과, 이해낱말의 경우 초기평가 시 6점(10\%ile), 진전평가 시 96점(75 100\%ile)으 로 나타났다(Figure 3A). 표현낱말의 경우 초기평가 시 2점(25\% ile) 진전평가 시 9점(50 75\%ile)을 나타내었다(Figure 3B). 제 스처와 놀이는 초기평가 시 23점(25 50\%ile) 진전평가 시 53점 (90\%ile 이상)을 나타내었다(Figure 3C). 아동의 각 영역별 점 수를 검사 안내서에서 제공하는 $50 \%$ ile 점수와 함께 Figure 3 에 제시하였다.

CSBS DP checklist를 실시하고 각 평가 항목을 Lee \& Jang (2004)이 제안한 영역별로 정리한 결과 비언어적 의사표현은 12 점, 언어적 상징은 10 점, 주의환기는 10 점으로 나타났다. Lee \& $\operatorname{Jang}(2004)$ 이 우리나라 영아를 대상으로 연구하여 보고한 결 과에서 12 개월 아동의 평균은 비언어적 의사표현 11.55점[stan- dard deviation $(\mathrm{SD})=2.59$ 점], 언어적 상징 6.87점 $(\mathrm{SD}=3.02$ 점), 주의 환기 6점( $\mathrm{SD}=2.15$ 점)으로, 대상 영아는 모든 영역에 서 또래 평균에 해당하거나 앞서는 결과를 나타내었다. CSBS $\mathrm{DP}$ 를 이용하여 아동의 행동에 나타나는 의사소통 기능발달을 직접 평가한 결과, 사회적 행동의 경우, 감정표현 및 눈맞춤은 13점, 의사소통은 16.3점, 제스처는 7점으로 나타났고, 언어 표 현의 경우 소리는 16 점, 단어는 4점으로 나타났다. 상징행동의 경우, 이해는 3점, 물건 사용은 9점으로 나타났다. 이 점수는 검사 안내서에서 제시한 미국 아동 규준을 참고했을 때 모두 50 95\%ile에 해당한다.

\section{전반적 발달}

$\mathrm{DEP}$ 를 이용하여 9개월에 전반적 발달을 평가한 결과, 전 영 역에 걸쳐 34.5 92.8\%ile, 총점 300점으로 해당월령에서 $65.5 \%$ ile(빠름)의 발달 수준을 보였다.

\section{DISCUSSIONS}

본고는 신생아 청각선별검사에서 일측성(우측) 고심도 난청 을 진단받은 9개월 남아를 대상으로 3개월간 총 9회의 부모교 육중심 조기 재활을 실시하고, 재활 전후의 초기평가와 진전평 가를 통해 영역별 발달정도를 확인하여 그 결과를 보고하였다. 


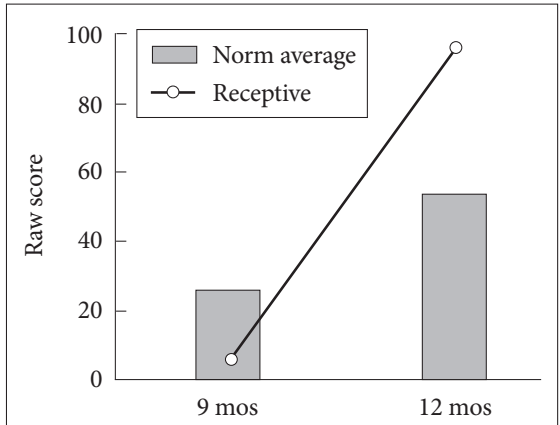

A

K MBCDI-receptive
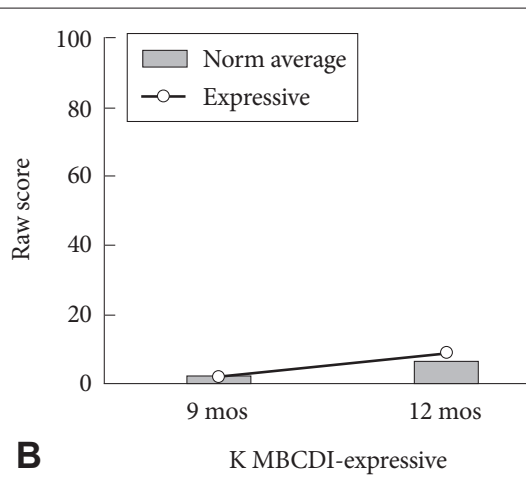

K MBCDI-expressive

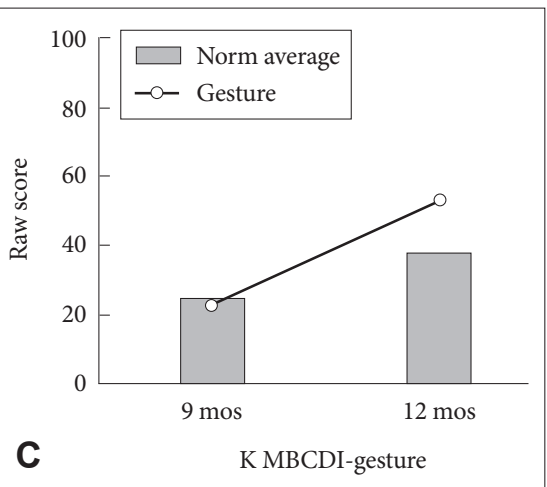

Figure 3. Language assessment outcomes using $\mathrm{K} \mathrm{MBCDI}$ at the first and second evaluation. $\mathrm{A}$ : $\mathrm{K} M B C D I$ receptive vocabulary. $\mathrm{B}$ : $\mathrm{K}$ MBCDI expressive vocabulary. C: K MBCDI gesture. The bar graphs show the normal means provided by the test manual, and the line above the bars shows the child's performance. K MBCDI: Korean MacArthur-Bates Communicative Development Inventories.

대상 영아는 초기평가에서 발성 및 말소리, 듣기, 언어 및 사회 적 의사소통의 평가 영역에서 또래 평균 범위에 해당하는 수행 을 보였으며, 3 개월 재활 후 진전평가에서도 모든 평가 영역에 서 또래와 비슷하거나 상회하는 결과를 나타내었다.

발성 및 말소리 영역의 경우, 초기평가에서는 1단계 발성이 2 단계 발성보다 더 많이 산출된 반면, 진전평가에서는 1단계 발 성이 줄어들고 2단계 발성이 증가하였다. SAEVD-R을 이용하 여 영유아의 발성발달을 연구한 Kim et al.(2015)에 따르면, 월 령이 증가할수록 하위단계의 발성이 줄어들고, 상위단계의 발 성이 증가하며, 9 12개월 월령구간에서는 2, 3, 4단계의 발성이 고루 나타나는 것으로 보고되었다. 본 영아의 발성분석 결과에 서도, $2,3,4$ 단계의 발성이 고루 나타났고, 월령이 증가함에 따 라 하위단계인 1 단계의 발성 산출이 $12 \%$ 에서 $2 \%$ 로 감소하여 영아의 발성산출이 안정적으로 나타나는 것을 확인할 수 있었 다. 즉, 이는 영아가 발달함에 따라 생리적인 소리가 줄어들고, 좀 더 성인의 말소리에 가까운 유사자모음 형태의 발성 산출이 증가하였음을 나타낸다. 3 5단계 발성은 초기평가와 진전평가 에서 비슷한 정도로 산출하는 것으로 분석되었는데, 이는 $\mathrm{SAEVD}-\mathrm{R}$ 의 3 5 단계 발성이 3 18개월에 걸쳐 서로 겹쳐서 나타나도록 구성되어 있기 때문인 것으로 풀이된다. 영아가 발 성에서 산출한 자음의 위치와 종류를 분석한 결과는 아동의 변 화를 좀 더 직접적으로 보여준다. 영아가 초기평가에서 산출한 자음은 초성에서 / T /, /ㄴ/, /ㅁ/, /ㅂ/, /빠/, 종성에서/ㄴ/, /ㅁ/이 었다. 그러나 3개월 진전 평가에서 초성과 종성 모두에서 그 수 가 크게 증가하였다. 초성에서는 초기평가에서의 5 개 자음 외 에 /ᄀᄀ/, /ᄃ/, /匹/, /ㅉ/, /ㅊ/, /E/, /ㅎ/ 등 모두 12개 자음을 산출 하였고, 종성에서는 7종성 중 /리을 제외한 모든 자음을 산출 하였다. 건청 영유아의 자음 산출을 보고한 선행 연구를 살펴 보면, 6 9개월에 /ㅁ/, /ㅂ/, /ᄀ/, /ㅁ/, /ㅂ/, /ㅈ/, 4 15개월 사이에 /ᄀ/, /ㅁ/, //, /ᄒ/, /ᄃ/, /匹/, /ㅂ/, /ᄂ/, /ス/, /ㄱ/, /ㅌ/, /프/(Kim et al., 2015), 12 24개월 사이에 /ㅁ/, /ㄴ/, /ᄀᄀ/, /т/, /匹/, /ᄃ/,
/ㅂ/, /삐/, /O/, /ㅎ(Moon \& Ha, 2012)을 산출한다고 보고하고 있다. 이와 비교하였을 때 본 사례연구 대상 영아가 선행연구에 서 보고한 자음 목록 대부분을 산출하고 있음을 확인할 수 있 다. 이는 본 사례연구 대상 아동의 자음 산출 영역이 또래 건청 아동과 비슷하게 발달하고 있음을 나타낸다.

듣기 영역은 $\mathrm{LEAQ}-\mathrm{K}$ 와 $\mathrm{CAP}$ 로 발달정도를 살펴보았다. 영 아는 LEAQ-K의 초기평가에서 19점, 진전평가에서 29점을 기 록하여 생활연령 증가에 따라 듣기 영역이 함께 발달하고 있음 을 나타냈다. 아동의 발달정도를 Son et al.(2015)에서 보고한 건청 또래 아동의 평균 예측값과 비교해 보았을 때, 두 번의 평 가 모두 또래 평균 범위에 해당하였다. 특히 Son et al.(2015)에 서 보고한 9 개월과 12 개월의 중간값과 비교했을 때, 본고의 대 상 영아는 12개월에 29점을 기록, Son et al.(2015)에서 보고한 중간값(23점)을 상회하여 그 발달속도가 다소 빠름을 알 수 있 다. 이는 영아가 우측의 심도 난청에도 불구하고 좌측의 정상 청력을 이용하는 듣기 기능이 건청인 또래와 다름없이 발달하 고 있음을 보여준다. $\mathrm{CAP}$ 를 이용한 평가에서는 범주 4에서 범 주 5 로 향상된 것으로 나타났다. CAP에서의 변화가 크지 않은 것은 평가지의 문항 특성에 기인한다. $\mathrm{CAP}$ 의 범주 4는 '독화 없이 약간의 말소리를 변별하는 것', 범주 5는 '독화 없이 일상 적인 구문을 이해하는 것', 그리고 범주 6은 '대화를 이해하는 것'을 가리킨다. 아동의 연령과 언어발달 정도를 고려했을 때 자주 들은 일상적인 구문의 이해는 가능하지만 대화를 이해하 는 것은 불가능하기 때문에 $\mathrm{LEAQ}-\mathrm{K}$ 에서 확인된 듣기 발달에 도 불구하고 $\mathrm{CAP}$ 에서는 1단계 향상에 그친 것으로 풀이된다. 영유아 언어발달에서 '자주 사용하는 말을 이해하는 것'이 생 후 약 10 개월경부터 가능하다는 것을 감안할 때, 만약 아동의 연령이 더 어렸다면 발달적으로 '일상적인 구문을 이해하는 것' 이 어려울 것이고 따라서 CAP에서의 점수 변화는 없었을 것이 라 추정할 수 있다. $\mathrm{CAP}$ 가 원래 인공와우 시술자의 듣기 기능 변화를 장기간 추적하기 위해 개발되었다는 점을 고려할 때, 이 
러한 결과는 CAP가 본 연구대상과 같은 영유아에게서 나타나 는 단기간의 듣기 기능 발달을 민감하게 반영하지 못할 수도 있음을 시사한다.

언어 영역은 전반적 언어발달, 어휘, 그리고 사회적 의사소통 으로 나누어 평가하였는데, 전반적 언어능력과 어휘 발달에서 눈의 띄는 변화가 있었다. SELSI를 이용한 전반적 언어발달 평 가 결과, 초기평가 시 수용언어와 표현언어 모두 50\%ile, 등가 월령은 아동의 생활연령(9개월)보다 1 개월 낮은 8 개월로 확인 되었으나, 3 개월 후(생활연령 12 개월)에 실시한 진전평가에서 는 수용언어 $65 \%$ ile로 등가월령 14 개월에 해당하였고, 표현언어 는 $90 \%$ ile로 등가월령 16 개월에 해당하여 특히 표현언어 부분에 서 큰 폭의 향상을 보였다. 이는 평균적인 발달 속도보다 다소 빠른 것이다. 여러 선행연구에서 부모교육 및 부모참여프로그램 이 발달지체 영유아의 표현 및 이해 어휘력과 의사소통행동(Lee, 2006), 문법적 형태소 발달과 발화길이(Lee, 2010)에 유의미한 향상을 미쳤다고 밝힌 것처럼, 본 사례의 조기재활에서 실시한 부모교육을 통한 가정에서의 집중적인 언어자극이 아동의 언어 발달에 긍정적인 영향을 준 결과로 생각된다. 이러한 결과는 $\mathrm{K}$ $\mathrm{MBCDI}$ 를 이용한 어휘발달 검사에서도 확인되었다. $\mathrm{K} \mathrm{MBCDI}$ 의 초기평가에서 표현낱말 2점(25\%ile), 이해낱말 6점(10\%ile), 제스처와 놀이 23점(25 50\%ile)를 기록하였으나, 3개월 후 진 전평가에서는 표현낱말 9점(50 75\%ile), 이해낱말 96점(75 $100 \%$ ile), 제스처와 놀이 53점(90\%ile 이상)으로 전 영역에 걸 쳐 25 65\%ile 이상의 향상을 보였다. CSBS DP checklist 결과 에서도 Lee \& Jang(2004)이 보고한 건청 또래와 비교하였을 때, 모든 영역에서 또래 평균 범주에 해당하였으며 특히 언어적 상징과 주의 환기 영역에서 각 10 점을 받아 각각 약 6 점인 또래 건청 아동의 평균을 상회하는 결과를 나타내었다. 부모 보고가 아닌, 12 개월에 CSBS DP를 이용한 사회적 의사소통발달의 직 접 평가 결과에서도 영아는 적절한 발달단계를 보였다. CSBS $\mathrm{DP}$ 를 이용한 직접 검사의 경우 한국 영유아의 평가 결과가 보 고되지 않아 검사 안내서에 제시된 미국 영유아 또래의 규준과 비교한 점은 본고의 한계이다. 그러나 문화와 언어의 차이로 인 해 미국의 규준을 그대로 적용하여 결과를 해석할 수 없다 해 도, CSBS DP가 주로 언어 이전 단계인 아동의 사회적 의사소통 행동을 평가대상으로 한다는 점을 고려할 때, 본 사례 연구 대 상 아동의 의사소통 행동 발달 정도를 가늠하는 데 참고할 수 있을 것이라 생각된다.

이상의 결과를 종합해 볼 때 본 사례연구 대상 영아는 생후 12 개월에 표준화된 검사 및 행동관찰에서 듣기 및 언어 발달 모두 평균 범위에 해당하는 결과를 보였으며, 재활 전 평가와 비 교할 때 특히 언어 영역에서 큰 변화가 있었다. 아동의 발달기에 있다는 점을 고려할 때 이는 아동의 자연스러운 발달의 결과일
수 있다. 그러나 표준화된 검사에서 그 발달의 변화 정도가 검 사 규준에 제시된 평균을 상회하고 있다. 또한 일측성 난청 영아 의 언어발달을 확인한 선행연구가 정상적 언어발달과 발달지체 를 모두 보고하고 있다는 점에서 일측성 고심도 난청은 언어발 달 지체를 보일 가능성이 있는 고위험군으로 분류된다. 따라서 본고의 대상 영아가 특히 언어발달에서 보인 변화는 아동의 정 상적인 발달에 아동의 부모가 참여한 적극적인 조기 재활 노력 이 더해진 결과일 수 있다. 이는 조기 재활을 받은 아동들의 언 어발달이 모두 정상발달 범주에 속했다는 선행연구 결과와 일 치하며, 이러한 결과는 신생아 청각선별검사에서 일측성 난청을 확인할 경우 언어발달 지체를 최소화하기 위해 적극적인 조기 재활이 필요하다는 주장을 지지한다(Fitzpatrick et al., 2015).

일측성 난청이 소음 상황에서의 말소리 지각 및 소리의 방향 변별에 어려움을 줄 뿐 아니라 언어발달 및 학업 수행, 그리고 심리·정서 발달에 이르기까지 아동 발달에 큰 영향을 미친다 는 것은 비교적 최근에 밝혀진 사실이다. 이에 여러 연구자들은 일측성 난청을 위한재활의 필요성에 공감하고 지금까지의 연구 를 기반으로 일측성 난청 아동의 재활 방향을 제안하고 있는 데, 이를 종합하면 크게 청각학적인 관리와 언어 및 학습적인 관리의 두 가지 방향으로 나누어 볼 수 있다(Bess et al., 1986; Ching et al., 2013; Firszt et al., 2015; Fitzpatrick et al., 2015; MacKay et al., 2008).

먼저 청각학적 관리의 출발점은 신생아 청각선별검사를 통 한 일측성 난청의 조기 발견이다(Bess et al., 1986). 일측성 난 청이 확인되면 부모뿐 아니라 이후 의사, 청능사, 언어재활사, 어린이집 및 유치원 교사 등은 아동의 변화에 주의를 기울여야 한다. 최근 연구 결과는 양이에 경도 난청이나 일측성 난청이 있 는 아동의 약 $30 \%$ 가 발달 과정에서 $20 \mathrm{~dB}$ 이상의 청력 악화를 경험한다고 보고하고 있다(Fitzpatrick et al., 2014). 그러므로 특 히 청능사는 청력 악화와 중이염 여부 등을 확인하기 위해 양 이를 모두 관찰해야 하고 변화가 관찰될 경우 즉시 적절한 조 치를 취해주어야 한다.

청각학적인 관리에서 두 번째로 고려할 수 있는 점은 적절한 보장구의 사용이다(Ching et al., 2013; Fitzpatrick et al., 2015; McKay et al., 2008). 아동을 대상으로 FM 시스템, 일반보청기, $\mathrm{CROS}$ 보청기, 그리고 이식형 골도 보청기(Bone-Anchored Hearing Amplification)가 일측성 난청의 청력손실로 인한 문 제를 처치하는데 어느 정도 도움이 되는가에 대한 연구는 아직 진행 중이다. 그러나 현재까지의 연구 결과를 바탕으로 일측성 난청 아동에게 보장구 사용을 권고하는 의견이 증가하고 있다. 이에 미국청각학회(American Academy of Audiology)에서는 ‘유소아 보장구 사용 가이드라인(Ching et al., 2013)'에서 일측 성 난청 아동의 보장구 사용을 권장하고 있다. 보장구의 사용 
을 다룬 문헌을 살펴보면, $\mathrm{FM}$ 보청기는 거의 모든 연구에서 경 도 및 일측성 난청 아동들의 언어인지도 상승에 도움이 된다는 점이 입증되어, 교사의 말소리 지각이나 이해가 어려운 일측성 난청 아동들에게 사용이 권고되고 있다(Tharpe et al., 2003; Updike, 1994). 필라델피아 아동병원의 재활 가이드라인에서는 25 65 dB HL 사이의 청력손실이 있는 일측성 난청 아동에게 일반보청기의 사용을 권장하고 있으며, 이를 사용한 경도 중등 도 일측성 난청 아동 및 청소년 28명 중 $72 \%$ 에서 전반적 듣기 기능의 향상 효과가 입증되기도 하였다(McKay, 2002; 2008). $\mathrm{CROS}$ 보청기와 이식형 골도 보청기의 경우는 연구마다 그 결 과가 상이하여, 말소리 인지 및 방향성 변별에 도움이 된다는 의견과(Hol et al., 2010; Priwin et al., 2007) 교실환경과 같이 큰 소음이 있을 때는 말소리 지각 및 방향성 변별에 큰 도움이 되지 않는다는 보고(Updike, 1994; Wazen et al., 2005)가 공 존한다. 그러나 대부분의 연구에서 공통적으로 이 두 가지 형 태의 보청기가 일측성 난청 아동의 구어 의사소통을 향상시키 고, 전반적인 삶의 질 향상에 도움이 된다고 보고하고 있어 재 활에 있어 두 보청기 사용에 대한 심층적인 연구의 필요성이 제 기되고 있다(Peters et al., 2015). 우리나라에서 일측성 난청 아 동을 대상으로 한 보장구 효과는 보고된 바가 없다. 한국 상황 에 맞는 적절한 보장구의 선택 및 사용효과에 대해 일관된 가 이드라인을 제시하기 위해서는 많은 연구가 필요하다.

언어 및 학습적인 관리를 위해서는 먼저 언어 선별검사를 통 해 언어장애의 위험을 확인해야 한다(Bess et al., 1986). 만약 언어선별검사에서 언어 지체가 확인되거나 심화 검사가 필요하 다고 확인되면 자발화 분석을 포함하여 전반적인 언어검사를 실시해야 한다. 일측성 난청이 듣기뿐 아니라 언어와 학습 등에 도 문제를 야기할 위험이 크다는 것이 밝혀짐에 따라, 여러 선 행연구에서는 지속적인 관찰과 주기적인 언어 평가의 중요성을 강조하고 필요한 경우 언어재활을 실시할 것을 권고하고 있다 (Hallmo et al., 1986). 또한 최근 일측성 난청 성인을 대상으로 소리의 방향성 변별을 목적으로 하는 청능훈련 효과가 보고되 었으나(Firszt et al., 2015), 아동에게서는 이러한 재활 사례를 찾지 못하였다. 청각자극이 대뇌 피질 청각 영역의 발달 및 조 직화에 직접 관여한다는 것은 여러 연구에서 이미 밝혀졌고 (Rouger et al., 2012), 일측성 난청 아동의 연구에서 난청 발생 방향에 따라 언어적/비언어적 과제의 수행 정도가 다를 수 있 다는 선행 연구를 고려할 때, 아동의 전반적 발달에 난청의 영 향을 최소화하기 위해 청능훈련이 필요할 수 있다. 그리고 교실 에서 일측성 난청 아동의 학업 수행에 도움을 주기 위해서는 아동의 자리를 교사의 얼굴을 잘 볼 수 있는 앞쪽에 배치하는 것이 좋다. 이는 아동과 교사와의 거리를 좁혀 아동이 교사의 말소리를 더 잘 들을 수 있을 뿐 아니라 교사의 얼굴을 더 가까
이 볼 수 있어 말소리 지각에 필요한 시각적인 정보를 더 많이 얻을 수 있게 된다. 더불어 정상 청력인 쪽의 귀가 소음이 덜 한 방향에 위치하거나 교사를 향할 수 있도록 방향을 조절하고, 교실 내의 소음을 최소화할 수 있도록 환경을 조성해야 한다 (Bess \& Tharpe, 1986; Oyler et al., 1987).

본 사례 보고에서는 조기청능재활에 부모교육을 비중 있게 포함하였다. 일반적으로 부모는 영아와 가장 많은 시간을 함께 보내며, 부모는 영아의 첫 번째 선생님이다. 따라서 영아의 재활 에 있어 부모의 역할과 가족의 참여는 매우 중요하다. Greenberg et al.(1984)는 청각장애 영아 가족을 대상으로 부모교육이 포함된 체계적인 재활의 효과를 입증하였는데, 부모교육이 포 함된 재활을 받은 영아가 그렇지 않은 영아보다 부모와의 상호 작용이 보다 안정적으로 나타났으며, 수용언어와 표현언어, 의 사소통 기술 또한 긍정적인 향상을 보였다. 본 사례에서는 KARI의 재활도구 중 '우리 아이와 매일매일 어떻게 말할까 요?, '일일점검표, '질문지' 등을 이용하여 부모교육을 실시함으 로서 구조화하고 체계적인 상담으로 효율성을 높였다. 구체적 인 부모 상담 내용에는 일반적으로 청각학적인 정보, 즉 진단 받은 난청의 종류와 정도, 난청의 특성, 의사소통에 미치는 영 향을 포함하였다. 따라서 일측성 난청 영유아의 경우, 언어발달 을 촉진하기 위한 부모 교육 이외에 여러 선행연구로부터 밝혀 진 문제들-양이합산 능력의 부재로 인한 소음상황에서의 말 소리 지각 및 소리의 방향 변별의 어려움, 언어 발달 및 학업 수 행에 미치는 영향, 심리·정서·사회성에 미치는 영향-에 대한 정보를 포함하여, 부모가 일측성 난청이 전반적인 발달에 미치 는 영향을 알고 대처할 수 있도록 일상생활에서 실질적인 예를 통해 이해할 수 있게 도왔다. 비록 본고가 1 사례를 대상으로 하 고 있고 부모의 참여 정도에 따라 그 결과가 달라질 수 있어, 본 고의 아동에게 나타난 결과를 모든 일측성 난청 아동에게 일반 화하기는 어려울 것이다. 그러나 특히 영유아기에 부모가 아동 에게 미치는 영향을 고려할 때, 이러한 부모교육은 특히 조기 재 활에서 매우 중요한 부분이라 생각된다.

본 사례 보고는 일측성 고심도 난청으로 진단받은 영아의 언 어발달 정도를 영역별로 평가하여 보고하고, 조기 재활을 실시 에 따른 긍정적인 효과를 확인하였으며, 이를 통해 부모가 참 여하는 적극적인 조기 재활이 일측성 고심도 난청 영아의 듣기 및 언어발달지체를 예방하거나 최소화할 수 있다는 점을 처음 으로 보고했다는 데 그 의의가 있다.

본 사례연구 대상 영아는 현재 보장구를 착용하지 않고 조용 한 환경인 가정에서 언어자극을 받고 있으나, 선행 연구의 권고 에 따라 향후 장기적인 측면에서 청각보조기기에 대한 상담이 이루어져야할 것이다. 또한 지속적이고 주기적인 청각 및 언어 평가를 통해 영아의 청력 변화 및 언어발달을 추적 관찰하여야 
할 것이다.

일측성 난청은 청력손실 정도에 관계없이 아동의 성장 과정 에서 언어발달, 의사소통, 학업 성취에까지 부정적인 영향을 미 칠 수 있기 때문에 보장구의 착용과 적극적인 조기 재활이 권 고된다(Ching et al., 2013; Fitzpatrick et al., 2015). 현재 국내 에서 일측성 난청이 아동의 전반적 발달에 미치는 영향이나 청 각 및 언어재활의 방향과 내용에 대한 연구는 전무한 실정이 다. 따라서 먼저 국내의 일측성 난청 아동들 대상으로 이 장애 군이 보일 수 있는 문제점을 확인하는 연구가 시급하다. 또한 최근 시행되기 시작한 신생아 청각선별검사 결과로 생후 12 개 월 이내에 난청 유무를 확인하고 조기에 재활을 시작하는 것이 가능해졌으므로, 청각 및 언어발달, 학습, 심리 정서 발달에 이 르기까지 일측성 난청 영아가 보일 수 있는 문제점들을 효과적 으로 예방하기 위해 부모교육을 중심으로 한 조기 재활에 대 한 연구가 필요할 것이다.

중심 단어 : 일측성/편측성 난청·신생아 청각선별검사·조기 재활· 영유아 청각재활 프로그램.

\section{Acknowledgments}

본 사례연구는 2015년 대한민국 교육부와 한국연구재단의 중견 연구자 지원사업(인문사회:H00159)지원을 받아 수행된 연구임 (NRF-2015S1A5A2A01011541).

\section{REFERENCES}

American Academy of Pediatrics, Joint Committee on Infant Hearing. (2007). Year 2007 position statement: Principles and guidelines for early hearing detection and intervention programs. Pediatrics, 120(4), 898-921.

Archbold, S., Lutman, M. E., \& Marshall, D. H. (1995). Categories of Auditory Performance. The Annals of otology, Rhinology and Laryngology, (Suppl 166), 312-314.

Bae, S. Y. \& Kowk, K. J. (2011). Korean MacArthur-Bates Communicative Development Inventories (K M-B CDI) Manual. Seoul: Mindpress.

Bess, F. H. \& Tharpe, A. M. (1986). Case history data on unilaterally hearing-impaired children. Ear and Haring, 7(1), 14-19.

Bess, F. H., Klee, T., \& Culbertson, J. L. (1986). Identification, assessment, and management of children with unilateral sensorineural hearing loss. Ear and Hearing, 7(1), 43-51.

Bess, F. H., Tharpe, A. M., \& Gibler, A. M. (1986). Auditory performance of children with unilateral sensorineural hearing loss. Ear and Hearing, 7(1), 20-26.

Borg, E., Risberg, A., McAllister, B., Undemar, B. M., Edquist, G., Reinholdson A. C., et al. (2002). Language development in hearing-impaired children. Establishment of a reference material for a 'Language test for hearing-impaired children', LATHIC. International Journal of Pediatric Otorhinolaryngology, 65(1), 15-26.

Bovo, R., Martini A., Agnoletto, M., Beghi, A., Carmignoto, D., Milani, M., et al. (1988). Auditory and academic performance of children with unilateral hearing loss. Scandinavian Audiology, (Suppl 30), 71S-74S.

Brookhouser, P. E., Worthington, D. W., \& Kelly, W. J. (1991). Unilateral hearing loss in children. The Laryngoscope, 101(12 Pt 1), 1264-1272.

Ching, T., Galster, J., Grimes, A., Johnson, C., Lewis, D., McCreery, R., et al. (2013). American Academy of Audiology Clinical Practice Guidelines. Pediatric Amplification. Retrieved from http://audiology-web.s3.amazonaws.com/migrated/PediatricAmplificationGuidelines.pdf_539 975b3e7e9f1.74471798.pdf.

Culbertson, J. L. \& Gilbert, L. E. (1986). Children with unilateral sensorineural hearing loss: cognitive, academic, and social development. Ear and Hearing, 7(1), 38-42.

Dancer, J., Burl, N. T., \& Waters, S. (1995). Effects of unilateral hearing loss on teacher responses to the SIFTER. Screening instrument for targeting educational risk. American Annals of the Deaf, 140(3), 291-294.

English, K. \& Church, G. (1999). Unilateral hearing loss in children. Language, Speech, and Hearing Services in Schools, 30, 26-31.

Firszt, J. B., Reeder, R. M., Dwyer, N. Y., Burton, H., \& Holden, L. K. (2015). Localization training results in individuals with unilateral severe to profound hearing loss. Hearing Research, 319, 48-55.

Fischer, C. \& Lieu, J. (2014). Unilateral hearing loss is associated with a negative effect on language scores in adolescents. International Journal of Pediatric Otorhinolaryngology, 78(10), 1611-1617.

Fitzpatrick, E. M., Durieux-Smith, A., Gaboury, I., Coyle, D., \& Whittingham, J. (2015). Communication development in early-identified children with mild bilateral and unilateral hearing loss. American Journal of Audiology, 24(3), 349-353.

Fitzpatrick, E. M., Whittingham, J., \& Durieux-Smith, A. (2014). Mild bilateral and unilateral hearing loss in childhood: a 20 -year view of hearing characteristics, and audiologic practices before and after newborn hearing screening. Ear and Hearing, 35(1), 10-18.

Greenberg, M. T., Calderon, R., \& Kusché, C. (1984). Early intervention using simultaneous communication with deaf infants: the effect on communication development. Child Development, 55(2), 607-616.

Hallmo, P., Møller, P., Lind, O., \& Tonning, F. M. (1986). Unilateral sensorineural hearing loss in children less than 15 years of age. Scandinavian Audiology, 15(3), 131-137.

Hol, M. K., Kunst, S. J., Snik, A. F., Bosman, A. J., Mylanus, E. A., \& Cremers, C. W. (2010). Bone-anchored hearing aids in patients with acquired and congenital unilateral inner ear deafness (Baha CROS): clinical evaluation of 56 cases. The Annals of Otology, Rhinology, and Laryngology, 119(7), 447-454.

Jang, H. S., Seo, S. J., \& Ha, J. Y. (2008). Developmental Assessment for the Early Intervention Program Planning (DEP). Seoul: Hakjisa.

Keller, W. D. \& Bundy, R. S. (1980). Effects of unilateral hearing loss upon educational achievement. Child: Care, Health and Development, 6(2), 93-100.

Kiese-Himmel, C. (2002). Unilateral sensorineural hearing impairment in childhood: analysis of 31 consecutive cases. International Journal of Audiology, 41(1), 57-63.

Kim, J. S., Jo, E. B., Ma, S. M., \& Yoon, J. E. (2015). A study for development of vocal production in Korean normal hearing infants. Audiology, 11(4), 348-365.

Klee, T. M. \& Davis-Dansky, E. (1986). A comparison of unilaterally hearing-impaired children and normal-hearing children on a battery of standardized language tests. Ear and Hearing, 7(1), 27-37.

Konkle, D. \& Schwartz, D. (1981). Binaural amplifi cation: a paradox. In Bess, F. B., Freeman, A., \& Sinclair S. Amplification in Education (pp. 345-357), Washington, DC: Alexander Graham Bell Association for the Deaf.

Korean Otology Society \& The Korean Audiology Society. (2011). Korean clinical practice guideline: newborn hearing screening 2010. Seoul: ML communication.

Lee, J. Y. \& Jang, Y. K. (2004). The preliminary study for the standardization of CSBS infant-toddler checklist. The Korean Journal of Human Development, 11(4), 37-54.

Lee, K. J. (2006). A parental education program's effect on a working mother with a child who has a communication disorder for the development of family support programs. Korean Journal of Family Welfare, 11(3), 33-52.

Lee, K. J. (2010). The effects of a small group parent involvement program for the abilities of syntax of language on developmentally delayed young children. Korean Journal of Family Welfare, 15(2), 47-64. 
Lieu, J. E. (2013). Unilateral hearing loss in children: speech-language and school performance. B-ENT, Suppl 21, 107-115.

Lieu, J. E., Tye-Murray, N., Karzon, R. K., \& Piccirillo, J. F. (2010). Unilateral hearing loss is associated with worse speech-language scores in children. Pediatrics, 125(6), el348-el355.

McKay, S. (2002). To aid or not to aid: children with unilateral hearing loss. Philadelphia, PA: Poster presented at the American Academy of Audiology Annual Convention.

McKay, S., Gravel, J. S., \& Tharpe, A. M. (2008). Amplification considerations for children with minimal or mild bilateral hearing loss and unilateral hearing loss. Trends in Amplification, 12(1), 43-54.

Ministry of Health and Welfare \& Centers for Disease Control and Prevention (2012). Korea Health Statistics 2011: Korea National Health and Nutrition Examination Survey (KNHANES V-2). Seoul: Ministry of Health \& Welfare.

Moon, H. W. \& Ha, S. H. (2012). Phonological development in toddlers with cleft palate and typically developing toddlers aged 12-24 months. Communication Sciences and Disorders, 2012(17), 118-129.

Nathani, S., Ertmer, D. J., \& Stark, R. E. (2006). Assessing vocal development in infants and toddlers. Clinical Linguistics and Phonetics, 20(5), 351-369.

Niedzielski, A., Humeniuk, E., Błaziak, P., \& Gwizda, G. (2006). Intellectual efficiency of children with unilateral hearing loss. International Journal of Pediatric Otorhinolaryngology, 70(9), 1529-1532.

Niskar, A. S., Kieszak, S. M., Holmes, A., Esteban, E., Rubin, C., \& Brody, D. J. (1998). Prevalence of hearing loss among children 6 to 19 years of age: the Third National Health and Nutrition Examination Survey. JAMA, 279(14), 1071-1075.

Oyler, R., Oyler, A., \& Matkin, N. (1987). Warning: a unilateral hearing loss may be detrimental to a child's academic career. The Hearing Journal, 9, 18-22.

Peters, J. P., Smit, A. L., Stegeman, I., \& Grolman, W. (2015). Review: Bone conduction devices and contralateral routing of sound systems in single-sided deafness. The Laryngoscope, 125(1), 218-226.

Prieve, B., Dalzell, L., Berg, A., Bradley, M., Cacace A., Campbell, D., et al. (2000). The New York State universal newborn hearing screening demonstration project: outpatient outcome measures. Ear and Hearing,
21(2), 104-117.

Priwin, C., Jönsson, R., Hultcrantz, M., \& Granström, G. (2007). BAHA in children and adolescents with unilateral or bilateral conductive hearing loss: a study of outcome. International Journal of Pediatric Otorhinolaryngology, 71(1), 135-145.

Rouger, J., Lagleyre, S., Démonet, J. F., Fraysse, B., Deguine, O., \& Barone, P. (2012). Evolution of crossmodal reorganization of the voice area in cochlear-implanted deaf patients. Human Brain Mapping, 33(8),19291940.

Ruscetta, M. N., Arjmand, E. M., \& Pratt, S. R. (2005). Speech recognition abilities in noise for children with severe-to-profound unilateral hearing impairment. International Journal of Pediatric Otorhinolaryngology, 69(6), 771-779.

Sedey, A. L., Carpenter, K., \& Stredler-Brown, A. (2002). Presentation at the National Symposium on Hearing in Infants: Unilateral Hearing Loss: What do we know, what should we do? Breckenridge, IL: Breckenridge, CO.

Shargorodsky, J., Curhan, S. G., Curhan, G. C., \& Eavey, R. (2010). Change in prevalence of hearing loss in US adolescents. JAMA, 304(7), 772-778.

Sohn, M., Kim, J., \& Park, H. (2015). Auditory development assessment with LittlEARS ${ }^{\circledR}$ auditory questionnaire in children with and without hearing loss. Audiology, 11(1), 45-62.

Tharpe, A. M., Ricketts, T., \& Sladen, D. P. (2003). FM systems for children with minimal to mild hearing loss. In D. Fabry \& C. D. Johnson. ACCESS: Achieving Clear Communication Employing Sound Solutions (pp. 191-197). Warrenville, IL: Phonak AG.

Updike, C. D. (1994). Comparison of FM auditory trainers, CROS aids, and personal amplification in unilaterally hearing impaired children. Journal of the American Academy of Audiology, 5(3), 204-209.

Wazen, J. J., Ghossaini, S. N., Spitzer, J. B., \& Kuller, M. (2005). Localization by unilateral BAHA users. Otolaryngol Head Neck Surg, 132(6), 928-932.

Wetherby, A. M. \& Prizant, B. M. (2001). Communication and Symbolic Behavior Scales Developmental Profile (CSBS DP). Baltimore, MD: The Brookes Publishing.

Yoshinaga-Itano, C., Sedey, A. L., Coulter, D. K., \& Mehl, A. L. (1998). Language of early- and later-identified children with hearing loss. Pediatrics, 102(5), 1161-1171. 